\title{
Solidarity at the Needle Point - the Intersection of Compassion and Containment during the A(H1N1) Pandemic in Sweden 2009
}

\author{
Britta Lundgren \\ Ethnology at the Department of Culture and Media Studies, Umeå University, Sweden
}

Copyright $(2016$ by authors, all rights reserved. Authors agree that this article remains permanently open access under the terms of the Creative Commons Attribution License 4.0 International License

\begin{abstract}
During the start of the A(H1N1) pandemic 2009, the WHO talked of the pandemic as an extreme expression of the global need for solidarity, and vaccination as the preferred national response. While seasonal vaccination mostly is framed as an individual benefit, the pandemic mass-vaccination in Sweden was framed in terms of solidarity. In the context of public health in Sweden, solidarity has worked as a rational evidence-based argument for politicians as proof of a reflexive and confident welfare nation. Solidarity was also perceived as an emotion that was possible to enact in bodily practice and would serve the goal of reaching herd immunity for the population. In this article these "politico-somatic" aspects of the pandemic preparedness and response are examined through qualitative methods such as ethnological interviews and fieldwork. The article discusses the entangled articulations of compassion and containment during the pandemic and how the side effect of narcolepsy from the vaccine Pandemrix disrupted the interpretations of solidarity as a relational concept. For the future, it is important to learn the lessons from the pandemic response, including how the issue of the side effect will influence coming preparedness and how the forces of compassion and containment will work. As long as it is not ignored, this side effect can enable the possibility to create strengthened reflexive awareness, which in turn strengthens public trust regarding possible future interventions.
\end{abstract}

Keywords A(H1N1) Pandemic, Side Effect, Narcolepsy, Vaccination, Compassion, Containment

\section{Introduction}

In the village of La Gloria in Mexico stands a statue of a little boy holding a frog in his hand. The boy is said to be the first to be diagnosed with the "swine flu", on April 27, 2009 , i.e. an index case. The statue is called Niño Cero [Little Boy Zero]. In a newspaper article, the boy's mother told the journalist that she was not happy about the sculpture. "Some people are saying my boy is to blame for everyone getting sick. I don't believe that." The sculptor said, "It portrays a child who was cured and who represents the union of all Mexicans." The frog was said to represent different plagues hitting humanity (The Mirror, July 25 2009)[1].

However, this little boy was not the first to be diagnosed and thus not an index case (cf. Acuña-Soto and Castañeda 2011)[2]. Still, the statue is one example of how the pandemic is "produced, suffered and remembered" to quote Kim Fortun (2001:6) [3]. It tells something about how the swine flu pandemic was framed as both a global and a national problem that particularly targeted children and young adults. However, considering how local authorities in La Gloria acted to frame the monument as a way to make La Gloria "live in glory", maybe the statue was mostly meant to serve as a tourist attraction (The Guardian, April 23 2010)[4].

\subsection{Aim and Methods}

My ethnological project (Epidemics, Vaccination and the Power of Narratives), which began in 2013, investigates different cultural and social aspects of the $\mathrm{A}(\mathrm{H} 1 \mathrm{~N} 1)$ pandemic in Sweden, especially the mass vaccination intervention and its following serious adverse effect. Throughout the project, I have worked with qualitative methods, such as interviews, observations, questionnaires, archive material, and media reports.

The aim of this article is to examine the entangled articulations of compassion and containment before and during the mass vaccination in Sweden and in the aftermath of the narcolepsy cases resulting from the Pandemrix vaccine. What Mika Aaltola has called the double movement of compassion and containment during pandemics (Aaltola 2012:19)[5] was already at the early start of the pandemic circulating as a mixture of facts, statements, rumours, and folklore in official declarations, in public and social media, 
and in people's everyday interactions.

My fieldwork using interviews was carried out to a great extent as parallel sessions with individuals from the following three groups comprising different social formations of the pandemic: 1) authorities, policymakers, and decision-makers, 2) patients (both narcolepsy patients and swine flu patients) and, 3) healthcare workers and medical researchers. This article is based on interviews with the first two groups. I have interviewed ten officials and decision-makers from different public health authorities and eight parents to children with narcolepsy as a side effect from Pandemrix vaccination. ${ }^{\mathrm{ii}}$ I have also interviewed two of the young adults who suffer from narcolepsy. The interviews were open-ended, but most often starting with some general questions concerning the informants' personal experiences of infectious diseases or pandemics, their individual roles or positions during the swine flu pandemic, and their attitudes toward vaccination in general and toward the 2009 mass vaccination in particular. The interviews were all digitally recorded and transcribed verbatim. I also used results from a questionnaire carried out in December 2009 from Lund Folk Life Archive (Lundgren 2015)[6] and a questionnaire sent out from the Swedish folk life archive at the Nordiska museet, Sweden's largest museum of cultural history (Lundgren 2015b)[7].

\section{Pandemic Preparedness and Response}

The initial warning about the $\mathrm{A}(\mathrm{H} 1 \mathrm{~N} 1)$-virus - the swine flu - came in April 21, 2009, from CDC Atlanta, reporting about two children in southern California with febrile respiratory illness. Not long thereafter it was shown that a new virus had already begun to spread in Mexico. It was also shown that the viruses in California and Mexico were identical, and it was evident that it was a pandemic strain. The epidemic passed the WHO pandemic Phase 4-5, and Phase 6 was officially declared on June 11, 2009 (ECDC Special Report 2010:6)[8]. In several statements, WHO officials focused on the novelty and unpredictability of the virus strain, on the need for global solidarity, and on the presence of H1N1 infection among the young as a key distinction for this pandemic (Abeysinghe 2015)[9]

The first influenza pandemic in over 40 years was now hitting the world and rapidly turning decades of influenza pandemic preparedness plans into different versions of pandemic responses. Since World War II, influenza vaccination has been the most favored technical solution to protect people from flu, whether seasonal or pandemic (Lundgren and Holmberg 2016) [10]. When the WHO decided to upgrade the pandemic and also focus on its implied seriousness - a judgement that has since been strongly questioned (cf. Abeysinghe 2015)[9] - a vaccination intervention with stockpiles of antivirals was considered to be the most rational choice for wealthy countries that had the critical infrastructure that was needed.
This was the case for many countries in Europe and the Western world, and Sweden was certainly well prepared to act in the face of a pandemic threat. The pre-pandemic planning had started already in 1993 with one of its most important ingredients being the advanced purchase agreement put in place in 2007 with a vaccine producer (GlaxoSmithKline) to guarantee delivery as soon as possible in case of a WHO declaration of a new pandemic (Socialstyrelsen [The National Board of Health and Welfare], 2011)[11].

The message about mass vaccination as the most important containment measure was made public in Sweden in the May 2009 pandemic plan, and the intervention started in October. The vaccine Pandemrix was recommended from the National Board of Health and Welfare together with other Swedish public health authorities as well as from politicians. It was free of charge for the whole population, and the intervention was implemented in a well-planned and efficient manner with over $60 \%$ uptake. This put Sweden in a position as a model, at least in Europe, due to this successful planning and implementation.

The whole of Europe wondered, how did you succeed? ... Our technology was so successful, we let nurses vaccinate, in France it was only the physicians who could do that. So, we could keep up the flow. People were admiring us in Norway and Finland, how could we be so effective? So, if that side effect had not turned up, we would have been in the top of the class and everybody would have been very proud (interview with decision-maker, February 2013).

The pandemic eventually turned out to be milder than expected with a low mortality. With the exception of some critique concerning the costs for the mass-vaccination intervention and the authorities' "crying wolf", Swedish politicians and medical authorities initially gained public confidence regarding their handling of the pandemic and of vaccination as the most important containment measure (Socialstyrelsen [National Board of Health and Welfare] 2011:61)[11]. However, in the spring and summer of 2010 (3-6 months after vaccination campaign) several vaccinated children and their parents in different parts of Sweden started to consult health professionals complaining about symptoms such as excessive sleep disturbances, fatigue, cataplexies, and paralyses. Eventually, reports were coming in to the Medical Products Agency about these concerns. In the course of 2010 and 2011, it was shown beyond doubt that the vaccine had caused an unexpected and very serious adverse effect - the lifelong neurological disease of narcolepsy (Läkemedelsverket [Medical Products Agency][12]. This unfolding tragic side effect turned the story of confidence and efficacy into a complicated narrative of compassion and containment, of mistrust, blame, defenses, excuses, condolences, vindications, and demands for responsible action from authorities (Lundgren and Holmberg 2016)[10]. 


\section{Vaccination as Compassionate Containment}

Beginning in April 2009, Swedish news media were filled with compassionate stories about people suffering from swine flu at intensive care units in the United States, Mexico, and Australia and about the deaths of relatively young individuals and the imminent threat of a mutant strain that eventually could make the epidemic/pandemic even worse. There were many alarming headlines about the virus, and eventually also about the vaccine, such as "The new contagion hits now. More and more deaths every day", "Wild quarrels about the vaccine", "This is where the virus hides", "Risk of contagion makes us change behaviour", "The first vaccine is here", "He died from the vaccine", etc. (Ghersetti and Odén 2010)[13]. As Mika Aaltola has observed, during a pandemic" compassionate worries over public health are entangled with alarm over the general uncontainability of global processes" (Aaltola 2012:19)[5]. Statements from Swedish politicians and public health authorities confirmed that children and young adults were at special risk of being infected and were at high risk of severe outcome (ECDC 2010:24)[7]. Thus, the statements shared the sentiment of compassion, but were also intermixed with confident and comforting messages about the national containment of the pandemic, including the well-prepared mass vaccination intervention as part of the Swedish pandemic preparedness plan.

\subsection{Solidarity and Responsibility - National Concerns with Historical Roots}

During pandemics, together with different grades of fear, solidarity and sense of responsibility are powerful compassionate forces. The solidarity argument has roots from the 1930s in Swedish welfare policies. The state has for decades been considered a natural actor in promoting the wellbeing of its citizens, including the concept of solidarity as a foundation for much of the public health work, albeit sometimes combined with a dose of repressivity (Lundberg 2008)[14]. Solidarity has been an underlying compassionate driver in Social-Democratic politics of the "people's home" and the well-known Swedish model. One official emphasized how politicians for a long time had used solidarity as arguments and that it now also appeared during the course of the pandemic.

This political objective was in fact long back in history ... we [at the National Board of Health and Welfare] had as a commission from the government purchased vaccine, so in that way there were very obvious signals from the political level about what they thought we should do (interview with decision-maker, February 2013).

Solidarity was also an important concept during the 1980s when Sweden formulated and expressed political awareness about inequalities as a threat to the welfare society, following the WHO's strategy Health for All (Vallgårda 2007:48)[15]. Sweden has also had a successful vaccine history with trust in general vaccine programmes and in seasonal influenza vaccination. One of my interviewees remembered his parents and the way they looked at what they considered a privilege, to take part in vaccination interventions.

I remember the older generation, they thought vaccinations were very important and it was almost kind of solemn to go and get vaccinated, it was not just a mundane question of routine (interview with decision-maker, February 2013).

What is indicated here is what sociologist Andrew Abbott has called the processual force of historicality of individuals. Abbott argues that individuals maintain continuity over time through aspects of historicality. The most important in this connection is the corporeal historicality of the "body itself, with its record of past exposure to disease, past use and misuse" (Abbott 2016:26)[16]. Other aspects of historicality are memorial - including "the presence of memories in minds" and recorded historicality such as literature, film, archiving, etc. (Abbott 2016:26)[16]. Older generations are claimed to have more vivid memories about diseases from times when vaccination was not the clear solution, whereas younger people show growing suspicion against things like vaccines. When the diseases are "gone", the vaccines seem to have lost their reason. Different opinion polls that were conducted before the onset of the mass vaccination indicated that people in general had a positive opinion about vaccination. However, because the public health authorities were tracing doubts about compliance among the young, special social media campaigns were directed towards this group.

One outspoken goal for the vaccination was to reach as high a compliance as possible to be able to achieve herd immunity in the population, which would also protect those who for different reasons could not get vaccinated and also to directly protect 'vulnerable' groups such as the chronically ill and the elderly. The vaccination recommendation was articulated as an act of solidarity - "protect yourself, protect others and prevent spread of disease" (Socialstyrelsen [The National Board of Health and Welfare] 2011)[11]. This explicit push on people to make the right choice created and enforced one important ethical issue that often arises in connection with pandemic flu or other serious contagious diseases, namely people's responsibility to avoid infecting others (Selgelid 2009:256)[17].

My fieldwork (Lundgren 2015; 2015c)[6;18] has shown that most people in Sweden did take this message seriously, especially when the argument was presented together with the outspoken risk for young people to fall seriously ill. The argument was strengthened by the emotional force from compassion and the technical drive of containment. In other words, the crowds of people lining up for vaccination constituted visible embodiments of both compassion and 
containment, connecting the most global with the most personal - at the needle point (Leach and Fairhead 2007:2)[19]. By both demanding the vaccine and obeying the authorities, people thus participated in a "hegemonic containment drama" (Aaltola 2012:53)[5], made visible through public messages in media, in airports, and in hospitals, where "the most distant embodiments - that is, individual bodies and world order - come into direct contact in pandemics and their scares" (Aaltola 2012:6)[5]. Although there were many factors that could be attributed to Abbott's concept of historicality (cohorts of people remembering actual diseases, etc.) to explain the high uptake, it is not completely clear how people motivated their decisions. In hindsight, the explanation was also often about the fear mongering or what people perceived as the exaggeration of threats (Lundgren 2015:57) [7].

Although voluntary vaccination as containment was very different from more coercive measures such as school closures or quarantines, it still carried elements of inclusion and exclusion. "All citizens" were expected to line up, but no special efforts were made to reach deprived and marginalized groups such as homeless people, asylum seekers, prisoners, etc. (Buccieri and Gaetz 2013; Kaposy and Bandrauk 2012)[20;21]. Some critical voices were raised concerning the fact that this kind of national containment enabled by special purchase agreements risked excluding people from countries with more underprivileged settings. The national discourse about Sweden and its ability as a welfare society to protect its citizens was often pronounced from public health authorities:

In a country like Sweden it is very hard to say 'we let some people $\operatorname{die}^{\prime} / . . . /$ this is something cultural that is different from many other countries (interview with decision-maker, March 2013).

Another official also remembered how Danish officials talked ironically about Sweden's use of safety measures: "You Swedes walk around with pillows all over the body" (interview with decision-maker, February 2013).

\section{2. "But it is a free choice"}

In addition to processes attributed to historicality and regulatory, expert-driven, and empowering governing technologies, appeals to autonomy, responsibility, and obedience have also been increasing since the 1990s. Signild Vallgårda has discussed the challenge for those in power to take advantage of the concept of new public health to make people choose by themselves in ways that are in line with how the government would like them to choose (Vallgårda 2011:30)[22]

People were supposed to act out of free choice, and to get vaccinated was something that each person should decide all by him or herself. In my interviews with officials, this was also pronounced, together with the view that it is wrong to use emotional arguments to make people do what authorities want them to do.

It is always the individuals that should decide, make their own choices. What we try to do is to gather enough information to enable the individual to choose, and then you should respect that choice (interview with decision-maker, March 2013).

Elsewhere (Lundgren 2015)[6] I have discussed the confusion and the complex circumstances and influences in everyday life that people reflected on when making the important decisions about vaccination. The confusion had its roots in the communication about the vaccination intervention, where on the one hand autonomy and free choice was expected, and on the other hand compassion and a call for solidarity motivated obedience regarding the need for containment of the pandemic.

Not surprisingly, the most outspoken critical voices regarding autonomy vs. obedience came from parents of children with narcolepsy. Some of the parents claimed that both solidarity and the free choice alternative was a chimera. Instead, they interpreted the individual decision-making processes as methods of social coercion.

\section{Yes, there was a choice. But then you would have to face so much social punishment if you make the wrong choice, so de facto it is not a choice ... this is such a clear form of abuse. Such social penance from neighbours, fellow citizens, authorities ... They stand there, all the big shots with power, and they tell in a commanding tone, people and subjects that you should vaccinate, and to hell with you if you don't obey (interview with parent, December 2012).}

According to the critical voices, the emotionally framed invigilation, both medially and socially, aimed to make people feel that they were both acting in their own right to protect themselves but also at the same time out of solidarity. Whatever dominated, these combined forces of compassion and containment contributed and coincided to make people place themselves in the queues "at the needle point".

\section{Waking up to Narcolepsy}

From the summer of 2010, reports started coming in to the Medical Products Agency (Läkemedelsverket)[12] about an unexpectedly large number of narcolepsy cases in children and adolescents after vaccination with Pandemrix. The cases of narcolepsy with cataplexy among vaccinated subjects have since risen to over 300 cases. Research has provided evidence that vaccination with Pandemrix for preventing the spread of swine flu was associated with a higher risk for narcolepsy with cataplexy in children/adolescents 19 years and younger. Sweden and Finland were the first countries to report this association with Pandemrix. Reports have since followed from England, Ireland, and Norway, and there are also some signs of association in France (Wijnans et al. 
2013)[23]. These reports indicate that the adverse effect was a European experience due to different countries' choices of vaccine and vaccine producer. The US did not use adjuvanted vaccine (such as Pandemrix), but Canada did, and one puzzling matter is that Canada used a similar vaccine from GlaxoSmithKline, but with somewhat different production methods (Jacob et al. 2015)[24].

Narcolepsy is a serious and debilitating chronic neurological condition characterized by excessive daytime sleep, cataplexies, hypnagogic hallucinations, and sleep paralyses as well as learning disabilities, depression, obesity, and disturbed metabolism. The disease is lifelong, and there is no existing cure, only symptomatic relief using different kinds of medication for sleeping disorders and cataplexies and central stimulants for sleepiness.

In my fieldwork, I interviewed several parents to children with narcolepsy from the vaccine and also two young adults that got the disease. The overall theme of the parents' stories dealt with the disruption that suddenly appeared in the lives of the families, and in addition to reasoning and negotiating about the troubles, the stories also dealt with morals, truth, guilt, and responsibility. The stories with their 'angry pathographies' indicated a strong need for critique not only about medication or treatment, but also about the etiology of the disease, the whole system of care, and even the whole of society and the "moral culpability of the state" (Hunsaker Hawkins 1999:128; Trundle and Scott 2013:503)[25;26]. The widespread use of the concept of solidarity, together with the political proclamation of the Swedish welfare model and the imperative obedience to WHO health policies, raised criticisms about Swedish authorities being too dependent on authorities in the EU and the WHO (Lundgren 2015).[18]

When the reports about the narcolepsy side effects started to go public, the first reaction from authorities and medical experts was scepticism. It appeared impossible that the vaccine could cause this unknown side effect because influenza vaccines had been used for 80 years without any similar side effects.

\subsection{Inhabiting the Contained Space of the Side Effect}

The side effect and the political struggles that the families had to go through, and still do, ${ }^{\text {iii }}$ have made the families question the interpretation of solidarity as a constitutive and relational concept for public health (Dawson and Jennings 2013)[27]. In my interview with a young woman with narcolepsy, she spoke of her experiences from the disease that she got after the vaccination when she was 17 years old. She talked of her daily cataplexies, her hallucinations, her sleepiness, and the side effects from the strong medications she must take. But most of all she talked about how she is now confined to live with her mother instead on her own. She is dependent on constant help from her mother and her boyfriend in a way that she finds humiliating - help with medication, help with staying awake or to be able to sleep, help with standing up instead of sleeping, etc. She thinks of herself as a burden to other people, and she explains how the disease totally dominates her life. It makes her afraid to live on her own, and she gives several examples:

If the fire alarm goes off I would not wake up. It would take me 20 minutes to get out of the sleep paralysis, and that is enough to be burned to death. So, I am quite afraid to live on my own, but there are special narcolepsy dogs, and we narcoleptics have the right to have them, but there is no financial support. ... Such a dog could alarm me if I would get a cataplexy somewhere public, it would wake me up in the morning, it would feel and understand why and when I need medication, and above all it would warn me and wake me up. Because that is the only way to wake me from a sleep paralysis, the living contact ... It doesn't help to use anything that vibrates, I have tried that, it doesn't work. So, but I cannot have this, I called the local community and asked those who work with disabled and their aids. But she only laughed ... and said you have to come with a more severe disability if you want help from us. ... That's how you are always treated from the authorities, they know nothing about narcolepsy. (interview with young adult, July 2014)

This woman's story told of an important aspect of the adverse effect. In the aftermath of the measures for containment of the pandemic, the narcoleptics and their families have experienced the containment of themselves, their removal into an unwanted space of societal failure and paradoxical feelings of shame and guilt.

The families experience that society and public health do not stand beside them any longer. As Dawson and Jennings (2013)[27] have argued, solidarity has to be interpreted as a relational emotion and foundation for practice. This is particularly important when solidarity is used in public health practice as a relational common good. The families claim that they embodied solidarity both in their decision to vaccinate and in their children's present and future lives as narcoleptics. They demand recognition in terms of reciprocal solidarity and social justice. Their interpretation is that the reciprocal relations between responsibility and solidarity have been neglected when it comes to their lives and individual struggles for acknowledgement and compensation (Lundgren and Holmberg 2016)[10]

\section{Solidarity at the Needle Point - If It Happens Again}

It is the coincidence, the coexistence of not knowing and global risks which characterizes the existential moments of decision not only in politics and science but also in everyday life situations (Beck 2016:104)[28].

Strangely enough, I never perceived the threat from the swine flu as very dangerous, in spite of having relatively small children at the time ... However, I 
understood that the authorities would never have started this big thing if there weren't any reason for it. I remember how well functioning everything was, the winding queues, everyone to the streets, everybody was there. Afterwards I don't remember if we ever got any information about the risks with vaccination, and anyway I would have considered those smaller than the risks from the flu. Most probably, I would get vaccinated again if there were a new threat. I trust medical science (KU 20949, woman born 1971).

The first quotation from Ulrich Bech concerns the inherent limitations to knowledge and the limitations to society's and individuals' ability to perceive and govern risk (Beck 2016:104).[28] The second quotation is part of an answer to a questionnaire about the pandemic that has been part of my fieldwork (Lundgren 2015) [7]. Although this woman reflects on the side effect that she now knows about, she would still trust authorities, or at least trust medical science.

Both quotations are about risk, fear, and insecurity. In his book The Pandemic Perhaps (2015)[29], social anthropologist Carlo Caduff performs an ethnographic exploration of pandemic prophecies in the United States (Caduff 2015:3)[29]. According to Caduff, pandemic prophecy looks both to the future and back to the past, and his goal is mainly to discuss how the prophetic also plays out in science. In 2016, I attended the large international conference Options $I X$ in Chicago. From the reading of, for example, Caduff, I realized that this was the place for both prophets and counter-prophets. Although some lecturers at the conference talked of "influenza fatigue" after the pandemic, some of the prophecies and the alarms are still out there. One example is Wenqing Zhang from the WHO who in her oral presentation "Pandemic planning-where are we?" ended with the message:

\section{Urgency - time is running out. Act now!}

Her final words, indicating the rush, the haste, and the speed that characterizes influenza science, and also a way to "keep up a steady drumbeat to motivate action" (Caduff 2015:10)[29], came after a long presentation about the massive work with intensified pandemic preparedness that has been carried out. She talked of all the milestones in pandemic preparedness since 1947, the International Health Regulations (IHR), the Pandemic Influenza Preparedness Framework (PIP), the WHO Pandemic Influenza Risk Management (PIRM), the Global Influenza Surveillance and Response System (GISRS), the Tools for Influenza Pandemic Risk Assessment (TIPRA), the Pandemic Influenza Severity Assessment Tool (PISA), the Global Action Plan for Influenza Vaccines (GAP), etc. Thus, her talk was filled with acronymic messages of comfort, but also stressing that time is running out and that there are organizational and logistical difficulties in handling all the procedures, the immense loads of information, and the competing goals. In the conference there was also much discussion about different mitigation methods and the effectiveness of vaccines and antivirals. However, neither in Wenqing Zhang's talk, nor (with one or two exceptions) in the other presentations, was there any mention or implication of the European narcolepsy experience or other potential side effects from antivirals or vaccines.

So, what would happen if there were to be a new pandemic and a new mass vaccination was proposed? Is there any evidence that, for example, Swedish pre-pandemic preparedness has been changed in any essential way from the time before the pandemic? One answer is found in the newspaper article "We would act in the same way if a new pandemic strikes" published in a Swedish newspaper on May 4, 2010, and signed by the Minister for Ageing and Public Health, the director for the Unit for Communicable Disease Prevention and Control at the National Board of Health and Welfare, and the chair of the Swedish Association of Local Authorities and Regions (Dagens Nyheter, May 4 2010)[30]. This was before the reports about narcolepsy. But after that? Not much has changed according to the new pandemic plan from 2012 (Socialstyrelsen[The National Board of Health and Welfare]; Holmberg and Lundgren 2016)[31;32]. The issue of side effects, or any mention of narcolepsy from the vaccination, is as absent in the new plan as it was in the previous one.

In my interview with one of these officials quoted in the newspaper article, I asked the same question. His answer circled around the issues of "knowns" and "unknowns" and the need for effective communication with the public. The point of the matter is that at the onset of the pandemic influenza vaccines were considered extremely safe after having been used for decades. That this specific vaccine would result in narcolepsy was so unlikely that it was regarded as impossible, even unthinkable, and that it would be very difficult to convince people again that a new vaccine would be safe when the impossible had happened.

We have to face reality; it will be very difficult to communicate the next time we come in a situation like this and that is extremely unfortunate, because we have no reason whatsoever to believe that the same risk [a new unexpected side effect] would occur again ... It is so incredible that it should not have happened. But it did. And the bad thing is that we still don't really understand why it happened. If we knew that we would do better in designing the next vaccine, so you wouldn't have to take the risk that we now obviously took without understanding it. And if we are lucky we will understand it the next time it happens and then it is not so hard. Then it is easier to communicate, we know what happened, now we have done this and this to make sure that this terrible combination will never emerge again (interview with decision-maker, February 2013).

In spite of this outspoken need for better communication, the news about a new purchase agreement for pandemic vaccine was presented very briefly in the spring of 2016 and with no further clarifications. The agreement was made with 
the same producer, GlaxoSmithKline, to be the supplier together with another producer. That GlaxoSmithKline got this new opportunity to make a lot of money from the pandemic vaccine created an outrage in social media, with questionings and expressions of distrust. It is hard to see that the authorities really tried to communicate better about the new agreement than the previous agreement in terms of technical and medical explanations for the side effect or how to prevent it the next time. The immense research that has been going on since 2010 has come a long way to understand the complicated immunological mechanisms that caused the autoimmune reactions (cf. Ahmed et al. 2014; Partinen et al. 2014)[33;34]. Although these scientific facts are difficult to explain in a popularized way, it is certainly possible to make some clear statements to the public. Instead, the communication about the new purchase agreement was very brief and with no explicit reference to the side effects during the pandemic. This also goes for the website of Folkhälsomyndigheten [The Public Health Agency of Sweden]. In the Questions and Answers part of the website and in news about the purchase agreement, narcolepsy is never mentioned. Instead, symbolic neglect (Caduff 2015:171)[29] is portrayed in euphemisms and paraphrasings such as "things that happened in 2009" (see the website https://www.folkhalsomyndigheten.se/sok/?q=pandemiavtal, retrieved 29 September, 2016).[35]

\section{Conclusions}

The mass vaccination has come to carry double symbolic meanings in Sweden - both success and failure - with the failure expressed as an 'Achilles-heel' by one of the officials (interview with decision-maker, February 2013). The pandemic with the mass vaccination constituted a "double movement of selective compassion and rigorous containment" (Aaltola 2012:19)[5] making up the politico-somatics of the $\mathrm{A}(\mathrm{H} 1 \mathrm{~N} 1)$ pandemic, the interlinkage between the global hierarchy of risk spread, the inequalities of disease burden, and individual fears of disease (Aaltola 2012:1).[5] In Sweden, the initial quest for solidarity, whether articulated as global or national, ended in conflicts about what solidarity involves in terms of responsibility and state culpability.

Pandemic narratives involve many kinds of protagonists some of them "public health heroes", such as health care workers, scientists, and some exceptional individuals who die fighting pandemics (Aaltola 2012:182).[5] In a more interconnected world, the pandemic narratives and the processes of compassion and containment work both to keep people together and to hold them apart.

The narcoleptic patients suffer from a very rare disease, about which both scientific and public knowledge is scarce. They do not live in the "kingdom of the sick", as described by Susan Sontag (Sontag 2001)[36], that is characterized by horrifying metaphors of decomposition of the body. Instead, they inhabit a space of political silence. Their narratives are mainly shared among their friends and families, on special social media communities, in the realm of their own association, and among their counterparts in other European countries. It is my impression from talking about the issue of the side effect in public gatherings, conferences etc., that the six years that have passed have erased much of the memories of the pandemic ("Yes, I remember now, we had a pandemic") and the knowledge of the side effect. What remains is often a blurred sense that "something went wrong".

That narcolepsy as a side effect from vaccination already has paved its way into the one-sided and demagogic argumentation from different forms of anti-vaccination movements is obvious. This constitutes an imminent health risk for the future. If it is in the interest of the state and its agents to maintain the public's basic trust in future pandemic interventions, then important lessons need to be learned. The mass vaccination in Sweden made the invisibility of side effects from influenza vaccination evolve into visibility. When actors of the state re-manufacture invisibility through silence and defense or shift the focus from the health effects to economic costs and administrative problems (cf. Beck 2016: p. 101)[28], hidden spaces of unwanted circumstances are created. When the knowledge about the narcolepsy experience is fragmented, toned-down, muted, or situated within specific national (European) domains, the global or cosmopolitical potentials for pandemic preparedness and response are also diminished. This actual side effect does in fact enable a possibility to create strengthened reflexive awareness, which in turn can strengthen public trust regarding possible future interventions.

Several important works have recently been written about A(H1N1), contributing to the critical epistemology (Farmer 2001:40)[37] of influenza pandemics - including Aaltola (2012)[5], MacPhail (2014)[38], Abeysinghe (2015)[9], and Caduff (2015)[29] to name but a few. To return to Kim Fortun (2001)[3], the pandemic is still produced, suffered, and remembered. The implications for the future are still not clear - or to put it in future anterior - we still don't know what the pandemic will have been.

\section{REFERENCES}

[1] The Mirror. "Statue erected of first boy in world who caught swine flu". 25 July, 2009. Retrieved at Sept. 13, 2016

[2] Acuña-Soto, R. and Castañeda, L., 2011. A perspective on the 2009 A/H1N1 influenza pandemic in Mexico. Mathematical Biosciences and Engineering, 2011; Vol.8, No 1., 2011:223-238.

[3] Fortun, K. Advocacy after Bhopal. Environmentalism, Disaster, New Global Orders. Chicago: The University of Chicago Press; 2001. 413 p.

[4] The Guardian. "La Gloria, swine flu's ground zero, is left with legacy of anger". 23 April, 2010. Retrieved at Sept. 13, 2016 
[5] Aaltola, M. Understanding the politics of pandemic scares. An introduction to global politosomatics. London and New York: Routledge; 2012. 208 p.

[6] Lundgren. B. "'Rhyme or Reason'? Saying no to mass-vaccination: subjective re-interpretation in the context of the A(H1N1) pandemic in Sweden 2009-2010." Medical Humanities 2015; 41(2): 107-112.

[7] Lundgren, B. The Common Cold, Influenza and Immunity in Post-pandemic Times: lay representations of self and other among older people in Sweden. 2015; Health, Culture, and Society 8(2): 46-59.

[8] ECDC Special Report. The 2009 (A(H1N1) pandemic in Europe. Stockholm: ECDC; 2010.

[9] Abeysinghe, S. Pandemics, science and policy. H1N1 and the world health organization. Edinburgh: Palgrave. 2015. 243 p.

[10] Lundgren, B. and Holmberg, M. Svininfluensapandemin i backspegeln. [The swine-flu pandemic in the rear view mirror]. Socialmedicinsk tidskrift 2016; 92(6) 683-695.

[11] Socialstyrelsen [The National board of Health and Welfare]. A(H1N1) 2009. An evaluation of Sweden's preparations for and management of the pandemic. Stockholm: The National Board of health and Welfare. 2011.Socialstyrelsen, [The National Board of Health and Welfare], A(H1N1) 2009. An evaluation of Sweden's preparations for and management of the pandemic. Stockholm, Sweden: The National Board of Health and Welfare. 2011.

[12] Läkemedelsverket, (Medical Products Agency) http://www.lakemedelsverket.se/Alla-nyheter/NYHETER-20 11/Rapport-fran-fallinventeringsstudie-om-Pandemrix-och-n arkolepsi/ 2011.

[13] Ghersetti, M. and Odén, T.A. Pandemin som kom av sig. Om svininfluensan i medier och opinion. [The Pandemic that Fizzled Out - swine flu in the media and in public opinion], Gothenburg; 2010. 149 p.

[14] Lundberg, A. Läkarnas blanka vapen. Svensk smittskyddslagstiftning i historiskt perspektiv. Nordic Academic Press. 2008. 256 p.

[15] Vallgårda, S.Health inequalities: Political problematizations in Denmark and Sweden. Critical Public Health 2007; 17(1): 45-56.

[16] Abbott, A. Processual Sociology. University of Chicago Press, 2016. 336 p.

[17] Selgelid, M.J. Pandethics. Public Health 2009; 123:255-259.

[18] Lundgren, B. "Narrating Narcolepsy - centering a side effect." Medical Anthropology 2015; 34(2)150-165.

[19] Leach. M. and Fairhead J. Vaccine Anxieties. Global Science, Child Health and Society. London: Earthscan. 2007. 224 p.

[20] Buccieri, K. and Gaetz, S. Ethical Vaccine Distribution Planning for Pandemic Influenza: Prioritizing Homeless and Hard-to-Reach Populations. Public Health Ethics 2013; Vol. 6, No. 2: 185-196.

[21] Kaposi, C. and Bandrauk, N.. Prioritizing Vaccine Access for Vulnerable but Stigmatized Groups. Public Health Ethics 2012; Vol. 5, No 3: 283-295.

[22] Vallgårda, S. Appeals to Autonomy and obedience: Continuity and Change in Governing Technologies in Danish and Swedish Health Promotion. Medical History, 2011;55: $27-40$.

[23] Wijnans, L., C. Lecomte, C. de Vries, D. Weibel, C. Sammon, A. Hviid, H. Swanström et al. The incidence of narcolepsy in Europe: Before, during and after the influenza A(H1N1) pdm09 pandemic and vaccination campaigns. Vaccine 2013; 31: 1246-1254.

[24] Jacob, L., Leib, R., Ollila, H.M., Bonvalet M., Adams, C.M., Mignot, E. Comparison of Pandemrix and Arepanrix, two pH1N1 AS03-adjuvanted vaccines differently associated with narcolepsy development. Brain, Behavior, and Immunity 2015; 47,44-57.

[25] Hunsaker-Hawkins, A. Pathography: patient narratives of illness. Culture and Medicine, 1999; Volume 171, 127-129.

[26] Trundle, C. and Scott, B.I.Elusive Genes: Nuclear Test Veterans' Experiences of Genetic Citizenship and Biomedical Refusal". Medical Anthropology: Cross-Cultural Studies in Health and Illness. 2013;32(6):501-17. doi: $10.1080 / 01459740.2012 .757606$.

[27] Dawson, A., \& Jennings, B. The place of solidarity in public health ethics. Public Health Review 2013; 34 (1), 65-79.

[28] Beck, U. The Metamorphosis of the World. Cambridge Polity Press. 2016. 200p.

[29] Caduff, C. The Pandemic Perhaps. Dramatic events in a public culture of danger. University of California Press. 2015. 296 p.

[30] Dagens Nyheter. "Vi agerar på samma sätt om en ny pandemic slår till" ["We would act in the same way if a new pandemic strikes"], May 4, 2010.

[31] Socialstyrelsen [The National Board of Health and Welfare] Beredskapsplanering för pandemisk influenza. Retrieved Sept. 29 at https://www.socialstyrelsen.se/Lists/Artikelkatalog/Att achments/18905/2012-12-7.pdf. 2012.

[32] Holmberg, M. and Lundgren, B. "Framing post-pandemic preparedness: Comparing eight European plans." Global Public Health 2016; http://dx.doi.org/10.1080/17441692.201 6.1149202

[33] Ahmed, S.S., Schur, P.H., MacDonald, N.E., \& Steinman, L. Narcolepsy, 2009 A(H1N1) pandemic influenza, and pandemic influenza vaccinations: What is known and unknown about the neurological disorder, the role for autoimmunity, and vaccine adjuvants. Journal of Autoimmunity 2014; 50, 1-11. doi:10.1016/j.jaut.2014.0

[34] Partinen, M. Rahbek Kornum, b., Plazzi, G., Jennum, P., Julkunen, I. Vaarala, O. Narcolepsy as an autoimmune disease: the role of H1N1 infection and vaccination. Lancet Neurol. 2014; Jun. 13(6) 600-13. https://dx.doi.org/10.1016/ S1474-4422(14)70075-4

[35] Folkhälsomyndigheten. Frågor och svar om pandemivaccin. [The Public Health Agency of Sweden. Questions and answers about pandemic vaccine]. Retrieved at Sept 29, 2016. https://www.folkhalsomyndigheten.se/sok/?q=pandemiavtal.

[36] Sontag, S. Illness as Metaphor and AIDS and Its Metaphors. New York: Picador. 2001.183 p.

[37] Farmer, P. Infection and Inequalities. The modern plagues. University of California Press, CA. 2001. 419 p. 
[38] MacPhail, T. The Viral Network. A Pathography of the H1N1-Pandemic. Cornell University Press. 2014. 248p.

i This article is an extended version of a paper given at the 76th Annual Meeting of the Society for Applied Anthropology (SfAA 2016), Vancouver, March 29 to April 2. The project is financed by Marcus and Amalia Wallenberg Foundation in Sweden. Ethics approval was from the Regional Ethical Review Board, May 29, 2012. (Dnr 2012-133-31)

ii I am grateful for information given from officials at the National Board of Health and Welfare, the European Centre for Disease Prevention and Control, the Medical Products Agency, and the Swedish Institute for Communicable Disease Control. I also would like to thank the Association for Narcolepsy (Narkolepsiföreningen) for providing information and providing the opportunity to interview parents to narcoleptic children.

iii So far this turning point with the appearance of narcolepsy as an adverse effect has left many remaining questions. The issue of social and economic compensation is still not completely solved. In fact, the Swedish Parliament voted in 2016 for a proposal, a compensations scheme, that was very much criticized from the Narcolepsy Association. 